\title{
WOJEWODA JAKO ORGAN NADZORU NAD DZIAŁALNOŚCIĄ JEDNOSTEK SAMORZĄDU TERYTORIALNEGO
}

DOI: http://dx.doi.org/10.12775/TSP-W.2020.005

Date of receipt: 27.07 .2020

Date of acceptance: 18.11 .2020

Province governor as the authority supervising the activities of local and regional government units. The article contains an analysis of selected issues related to the problem of supervision over the activities of local and regional government. The problem was characterized in comparison with the most important constitutional authority appointed for this purpose, i.e. the province governor. I began my deliberations with an analysis of supervision in the constitutional context. I then went on to a presentation of my views concerning two closely related concepts: control and supervision. Another element of the article is the presentation of the province governor - his or her position in the structure of power, with simultaneous presentation of selected powers and duties, mainly in the context of the supervision he or she performs in relation to local and regional government units. Another very important element of the paper is a short description of the topic of supervision, the criterion of supervision, and the supervisory measures that a province governor is entitled to in relation to local and regional government units. Almost every part of the article refers to numerous views expressed in the doctrine, the current legislation, and the relevant case law. Without the presentation of the case law, it would not have been possible to interpret the issues in question correctly. The paper ends with a brief summary.

${ }^{1}$ Dr hab. Stanisław Bułajewski - Katedra Prawa Konstytucyjnego, Wydział Prawa i Administracji, Uniwersytet Warmińsko-Mazurski, Olsztyn, ORCID: 0000-0002-7067-4153, e-mail: stabul1@wp.pl. 
Keywords: supervision; control; province governor; local government; constitution.

Streszczenie. W ramach artykułu została przeprowadzona analiza wybranych kwestii, związanych z problematyką nadzoru nad działalnością samorządu terytorialnego. Problematyka ta została scharakteryzowana w konfrontacji z najważniejszym konstytucyjnym podmiotem do tego powołanym, $\mathrm{tj}$. z wojewodą. Swoje rozważania rozpocząłem od analizy nadzoru w kontekście konstytucyjnym. Następnie przeszedłem do próby przedstawienia poglądów na temat dwóch ściśle powiązanych ze sobą pojęć, a mianowicie do pojęcia kontroli i pojęcia nadzoru. Kolejnym elementem artykułu było przedstawienie wojewody - jego umiejscowienia w strukturze władzy, z jednoczesnym zaprezentowaniem wybranych uprawnień i obowiązków, głównie w kontekście nadzoru, jaki ten organ pełni w stosunku do jednostek samorządu terytorialnego. Niezwykle istotnym elementem pracy była również krótka charakterystyka przedmiotu nadzoru, kryterium nadzoru oraz środków nadzorczych, jakie w stosunku do jednostek samorządu terytorialnego wojewodzie przysługują. Niemal każda część artykułu odnosiła się do licznych poglądów doktryny, aktualnego prawodawstwa i orzecznictwa. Bez prezentacji owego orzecznictwa nie byłoby możliwe prawidłowe zinterpretowanie spornych kwestii. Całość zwieńczyło krótkie podsumowanie.

Słowa kluczowe: nadzór; kontrola; wojewoda; samorząd terytorialny; konstytucja.

\section{NADZÓR - PODSTAWY KONSTYTUCYJNE}

Jak słusznie zauważono, ,nadzór nad samorządem terytorialnym jest jednym z podstawowych wyznaczników jego samodzielności oraz charakteru prawnego relacji występujących między samorządem a organami administracji rządowej w strukturze zdecentralizowanej. Podłożem, na jakim ukształtowała się instytucja nadzoru nad samorządem terytorialnym, była konieczność zintegrowania działań wszystkich podmiotów prawa publicznego, zarówno działających na zasadzie decentralizacji, jak i tworzących strukturę administracji publicznej (B. Dolnicki, Nadzór nad samorządem, s. 29). Jak zauważył S. Kasznica, ilekroć państwo przyznaje komukolwiek cząstkę władzy, tylekroć zastrzega sobie prawo nadzoru nad sposobem jej wykonywania (S. Kasznica, Polskie prawo administracyjne, s. 75). Art. 171 wyznacza podstawowe zręby tego nadzoru, o których następnie stanowią ustawy samorządowe w oddzielnych rozdziałach poświęconych nadzorowi oraz wiele ustaw z zakresu materialnego prawa administracyjnego. Nadzór nad samorządem terytorialnym z jednej strony jest przejawem ograniczenia jego samodzielności oraz powiązania wszystkich organów władzy publicznej w jeden organizm państwowy. $Z$ drugiej strony nadzór chroni samorząd terytorialny przed niezgodną z prawem ingerencją ze strony pań- 
stwa i jest istotnym elementem składowym pojmowania decentralizacji władzy publicznej"2.

Art. 171 ust. 2 Konstytucji RP wyraźnie stanowi: „Organami nadzoru nad działalnością jednostek samorządu terytorialnego są Prezes Rady Ministrów i wojewodowie, a w zakresie spraw finansowych regionalne izby obrachunkowe"3. Samorządowe ustawy ustrojowe ${ }^{4}$ wskazują, iż uprawnienia dotyczące stosowania środków nadzoru nad jednostkami samorządu terytorialnego przysługują także Sejmowi RP oraz ministrowi właściwemu do spraw administracji publicznej ${ }^{5}$. Moim zdaniem także sądy administracyjne oraz samorządowe kolegia odwoławcze maja pewne uprawnienia o charakterze nadzorczym ${ }^{6}$.

W tym miejscu warto przypomnieć, iż polskie regulacje konstytucyjne dotyczące nadzoru nie są regulacjami nowymi. O nadzorze nad działalnością samo-

${ }^{2}$ Podaję za: M. Safjan, L. Bosek (red.), Konstytucja RP, tom III, Warszawa 2016, wyd. 1 / Skoczylas/Piątek - wydawnictwo elektroniczne Legalis, dostęp - 1 lipca 2020 r.

${ }^{3}$ Konstytucja Rzeczypospolitej Polskiej z dnia 2 kwietnia 1997 r., Dz. U. z 1997 r., nr 78, poz. 483 z późn. zm.

${ }^{4}$ Ustawa z dnia 8 marca 1990 r. o samorządzie gminnym, tekst jedn. Dz. U. z 2020 r., poz. 713 z późn. zm.; ustawa z dnia 5 czerwca 1998 r., tekst jedn. Dz. U. z 2020 r., poz. 920 z późn. zm.; ustawa z dnia 5 czerwca 1998 r. o samorządzie województwa, tekst jedn. Dz. U. z 2019 r., poz. $512 \mathrm{z}$ późn. zm.

${ }^{5}$ Przykładowo zgodnie z art. 96 ustawy o samorządzie gminnym w razie powtarzającego się naruszenia przez radę gminy Konstytucji lub ustaw Sejm, na wniosek Prezesa Rady Ministrów, może w drodze uchwały rozwiązać radę gminy. W przypadku rozwiązania rady gminy Prezes Rady Ministrów, na wniosek ministra właściwego do spraw administracji publicznej, wyznacza osobę, która do czasu wyboru rady gminy pełni jej funkcję. Jeżeli powtarzającego się naruszenia Konstytucji lub ustaw dopuszcza się wójt, wojewoda wzywa wójta do zaprzestania naruszeń, a jeżeli wezwanie to nie odnosi skutku - występuje z wnioskiem do Prezesa Rady Ministrów o odwołanie wójta. W przypadku odwołania wójta Prezes Rady Ministrów, na wniosek ministra właściwego do spraw administracji publicznej, wyznacza osobę, która do czasu wyboru wójta pełni jego funkcję.

Stosownie zaś do art. 97 ustawy o samorządzie gminnym, w razie nierokującego nadziei na szybką poprawę i przedłużającego się braku skuteczności w wykonywaniu zadań publicznych przez organy gminy Prezes Rady Ministrów, na wniosek ministra właściwego do spraw administracji publicznej, może zawiesić organy gminy i ustanowić zarząd komisaryczny na okres do dwóch lat, nie dłużej jednak niż do wyboru rady oraz wójta na kolejną kadencję. Ustanowienie zarządu komisarycznego może nastąpić po uprzednim przedstawieniu zarzutów organom gminy i wezwaniu ich do niezwłocznego przedłożenia programu poprawy sytuacji gminy. Komisarza rządowego powołuje Prezes Rady Ministrów na wniosek wojewody, zgłoszony za pośrednictwem ministra właściwego do spraw administracji publicznej. Komisarz rządowy przejmuje wykonywanie zadań i kompetencji organów gminy z dniem powołania.

${ }^{6}$ Zob. szerzej S. Bułajewski, Rada powiatu, pozycja ustrojowa, stanowienie prawa $i$ kontrola, Olsztyn 2009, s. 246, s. 258-262. 
rządu stanowił po raz pierwszy art. 70 Konstytucji marcowej ${ }^{7}$, a następnie art. 75 ust. 5 Konstytucji kwietniowej ${ }^{8}$. W Konstytucji z 1921 r. nadzór nad samorządem był sprawowany przez wydziały samorządu wyższego stopnia. Mógł on jednak zostać przekazany w drodze ustawy częściowo sądownictwu administracyjnemu. Zgodnie z postanowieniami Konstytucji z 1935 r. nadzór był sprawowany przez rząd działający przez swoje organy i przez organy samorządu wyższego stopnia.

Konstytucja PRL z 1952 r. ${ }^{9}$ w ogóle nie regulowała problematyki nadzoru nad samorządem terytorialnym.

Natomiast Mała Konstytucja ${ }^{10}$ kwestie nadzoru nad samorządem terytorialnym regulowała krótko w art. 74, zgodnie z którym nadzór nad działalnością jednostek samorządu terytorialnego określa ustawa. Na bazie tego unormowania Trybunał Konstytucyjny, analizując art. 74 tzw. Małej Konstytucji, wskazał, że zawiera on »trzy implikacje «:

1) „ustala zasadę nadzoru, tj. poddaje kontroli działalność samorządu terytorialnego, z prawem jej modyfikowania, a nie tylko formułowania wniosków pokontrolnych przez właściwe organy;

2) określa, iż ,zakres ani kryteria nadzoru nie ograniczają się tylko do gospodarki finansowej gmin;

3) jak również stanowi że ,utworzenie organów nadzoru, określenie ich pozycji i kształtu instytucjonalnego, zasad i form jego działania, powierzone zostało ustawie" 11 .

\section{ZAGADNIENIA OGÓLNE (KONTROLA A NADZÓR)}

Kontrola i nadzór pozostają ze sobą w największej styczności ${ }^{12}$. Jednakże przedstawiciele doktryny definiują nadzór w różny sposób. Przykładowo J. Starościak pisał, że „tam, gdzie w grę wchodzi prawo obserwacji plus prawo wydawania poleceń, będziemy mówili o nadzorze nad organami administra-

${ }^{7}$ Ustawa z dnia 17 marca 1921 r. - Konstytucja Rzeczypospolitej Polskiej, Dz. U. z 1921 r., nr 44, poz. 267.

${ }^{8}$ Ustawa Konstytucyjna z dnia 23 kwietnia 1935 r., Dz. U. z 1935 r., nr 30, poz. 227.

${ }_{9}$ Konstytucja Polskiej Rzeczypospolitej Ludowej uchwalona przez Sejm Ustawodawczy w dniu 22 lipca 1952 r. Dz. U. z 1952 r., nr 33, poz. 232

${ }^{10}$ Ustawa Konstytucyjna o wzajemnych stosunkach między władzą ustawodawczą i wykonawczą Rzeczypospolitej Polskiej oraz o samorządzie terytorialnym z dnia 17 października 1992 r., Dz. U. z 1992 r., nr 84, poz. 426.

${ }_{11}$ Orzeczenie Trybunału Konstytucyjnego z dnia 18 stycznia 1994 r., sygn. akt K 9/93, OTK 1994, nr 1, poz. 3.

12 J. Jagielski, Kontrola administracji publicznej, Warszawa 2006, s. 18. 
cyjnymi. Nadzór nie ogranicza się zatem do obserwacji, ale łączy się z czynnikiem kierowania przez wydawanie dyrektyw"13. Według J. Homplewicza ,jjeżeli przez nadzór rozumiemy całokształt uprawnień organu wyższego do ingerencji w działalność i organizację organu podległego - to nietrudno stwierdzić, że kontrola podejmowana przez organ nadrzędny w stosunku do podległego stanowi jeden z elementów nadzoru"14. Natomiast M. Wierzbowski wskazywał, iż termin nadzór ,[...] jest używany najczęściej do określenia sytuacji, w której organ nadzorujący jest wyposażony w środki oddziaływania na postępowanie organów nadzorowanych, nie może jednak tych organów wyręczać w ich działalności. Uprawnienia nadzorcze oznaczają uprawnienia kontrolne wraz z możliwością wiążącego wpływania na organy czy instytucje nadzorowane. W niektórych przypadkach mianem nadzoru oznacza się również kierownictwo"15. Także najnowsza doktryna wypowiada się w podobny sposób. Przykładowo M. Miemiec stwierdza, iż nadzór ,[...] oznacza kompetencję (możność i powinność prawną) władczego wkraczania właściwego nadrzędnego (organizacyjnie bądź funkcjonalnie) organu administracji publicznej w działalność organu (podmiotu) nadzorowanego. Zadaniem nadzoru jest zabezpieczenie realizacji celów administracji publicznej i utrzymanie jej działalności w granicach prawa. Inaczej mówiąc nadzór jest prawnie określonym mechanizmem scalającym w ramach aparatu państwowego podmioty administracji publicznej"16.

Wydaje się jednak, iż najtrafniej nadzór (w powiązaniu z pojęciem kontroli) zdefiniował E. Ochendowski: „Nadzór jest pojęciem szerszym niż kontrola. Nadzór obejmuje zawsze kontrolę, natomiast wykonywanie kontroli nie musi się łączyć z prawem stosowania środków nadzorczych. O nadzorze mówi się wówczas, gdy w grę wchodzi prawo wydawania poleceń, wiążących dyrektyw co do zmiany kie-

${ }_{13}$ Zob. J. Starościak, Zarys nauki administracji, Warszawa 1971, s. 356, zob. także J. Starościak, Prawo administracyjne, Warszawa 1975, s. 346.

${ }^{14}$ Por. J. Homplewicz, Ogólne zagadnienia prawne kontroli administracji, „Kontrola Państwowa" 1965 , z. 4, s. 2.

${ }^{15} \mathrm{M}$. Wierzbowski, Nadzór w systemie rad narodowych i terenowych organów administracji, [w:] J. Służewski (red.), Terenowe organy administracji i rady narodowe po reformie, Warszawa 1977, s. 266. Autor w niniejszej publikacji wyróżnia różne postacie nadzoru oraz charakteryzuje pojęcie kontroli.

${ }^{16}$ M. Miemiec, Nadzór i kontrola nad samorządem terytorialnym, [w:] W. Miemiec, B. Cybulski (red.), Samorzadowy poradnik budżetowy na 1997 r. Zagadnienia ustrojowe i prawno-finansowe, Warszawa 1997, s. 73; zob. także: J. Boć, Kontrola administracji, [w:] J. Boć (red.), Administracja publiczna, Kolonia Limited 2003, s. 334-335; P. Chmielnicki, Nadzór nad działalnościq samorzqdu terytorialnego. Rozważania de lege ferenda, „Przegląd Legislacyjny” 2004, nr 5, s. 9-21; M. Szewczyk, Nadzór w materialnym prawie administracyjnym, Poznań 1995, s. 26 i n.; B. Dolnicki, Nadzór nad samorzqdem terytorialnym, Katowice 1993, s. 41 i n.; A. Filipowicz, Pojęcie i funkcje nadzoru w administracji, Wrocław - Warszawa - Kraków - Gdańsk 1985, s. 119 i n. 
runków działania. Nadzór nie ogranicza się zatem do obserwacji i ustaleń stanu faktycznego, ale łączy się z możliwością stosowania środków nadzoru"17. W podobny sposób instytucję nadzoru ujął Trybunał Konstytucyjny, według którego przez nadzór należy rozumieć określone procedury uprawniające odpowiednie organy państwowe, wyposażone w stosowne kompetencje, nie tylko do ustalania stanu faktycznego, ale i korygowania działalności organu nadzorowanego ${ }^{18}$.

Godny uwagi jest także fakt, iż wielokrotnie próbowano podać definicje legalne zarówno pojęcia kontroli, jak i nadzoru. Przykładowo pod koniec lat osiemdziesiątych Radzie Legislacyjnej, która podjęła wtedy inicjatywę ustanowienia ogólnych przepisów prawa administracyjnego, udało się (po wielokrotnych modyfikacjach) ustalić następujące określenia:

„Kontrola - czynności sprawdzające, podjęte dla ustalenia zgodności działania podmiotu kontrolowanego $\mathrm{z}$ wymaganym kryterium oraz sformułowania w miarę potrzeby wniosków w celu usunięcia stwierdzonych uchybień lub wprowadzenia usprawnień" 19 .

„Nadzór - jest to kontrola oraz możność podjęcia prawem przewidzianych środków wiążących nadzorowanego lub możność bezpośredniego wzruszenia jego aktów. Jeżeli przepisy nie określają nadzorczej ingerencji, określenie »nadzór« traktuje się jako oznaczające wyłącznie kontrolę"20.

\section{WOJEWODA JAKO ORGAN NADZORU}

Wojewoda jest konstytucyjnym organem państwa już od 1990 r. Konstytucja RP z 2 kwietnia 1997 r. w art. 152 określiła, że „przedstawicielem Rady Ministrów w województwie jest wojewoda”, zaś „tryb powołania i odwołania oraz zakres działania wojewodów określa ustawa". Tak więc zarówno art. 152 Konstytucji RP, jak i art. 171 ust. 2 Konstytucji RP determinują pozycję normatywną tego organu oraz tworzą podstawy dla określenia pozycji wojewody w ustawach zwykłych. Wojewoda działa w sferze politycznej, jako przedstawiciel Rady Ministrów, natomiast jako organ nadzoru realizuje swoje kompetencje, kierując się kryterium legalności. Wojewoda wypełnia również funkcję organu administracji publicznej, którego jednym z zadań jest rozstrzyganie o prawach i obowiązkach

\footnotetext{
17 E. Ochendowski, Prawo administracyjne część ogólna, Toruń 2005, s. 407.

${ }^{18}$ Uchwała Trybunału Konstytucyjnego z dnia 5 października 1999 r. (Dz. U. nr 113, poz. 551).

19 Podaję za: S. Jędrzejewski, Teoretyczne problemy rozgraniczenia pojęć „,kontrola” $i$,,nadzór”, [w:] S. Jędrzejewski, H. Nowicki, Kontrola administracji publicznej, Toruń 1995, s. 10.

${ }^{20}$ Ibidem.
} 
podmiotów administracyjnych. Jak słusznie zauważył Marek Chmaj - niezwykle doniosły jest art. 103 ust. 1 Konstytucji RP, który określa zasadę niepołączalności. „W przypadku wojewody niepołączalność należy traktować przede wszystkim jako realizację podziału władzy, a nie uzależnienie od determinant politycznych. Zarysowany w Konstytucji RP status wojewody należy postrzegać także w kontekście jej art. 15, mającego brzmienie »ustrój terytorialny Rzeczypospolitej Polskiej zapewnia decentralizację władzy publicznej. Zasadniczy podział terytorialny państwa uwzględniający więzi społeczne, gospodarcze lub kulturowe i zapewniający jednostkom samorządu terytorialnego zdolność wykonywania zadań publicznych określa ustawa«. Wojewoda pozostanie więc organem terenowym pozostającym $\mathrm{w}$ stosunku do organów samorządu terytorialnego w relacjach zdecentralizowanych, a zakres jego właściwości obejmuje granice danego województwa, które powinno mieć rozmiar umożliwiający zachowanie więzi określonych w ustawie zasadniczej" ${ }^{21}$.

Będące przedmiotem analiz przepisy zostały uszczegółowione przez ustawy zwykłe. Stanowią one doprecyzowanie, rozwijają i uszczegóławiają status konstytucyjny wojewody ${ }^{22}$. Podstawowym aktem prawnym regulującym funkcjonowanie wojewody oraz terenowej administracji rządowej jest ustawa $\mathrm{z}$ dnia 23 stycznia 2009 r. o wojewodzie i administracji rządowej w województwie ${ }^{23}$. Organizacyjne podstawy prawne działania administracji rządowej w województwie zawarte są również w samorządowych ustawach ustrojowych oraz ustawach regulujących wycinkowe zagadnienia funkcjonowania tej administracji, a odnoszących się do poszczególnych służb, inspekcji i straży.

Wojewodę powołuje i odwołuje Prezes Rady Ministrów na wniosek ministra właściwego do spraw administracji publicznej ${ }^{24}$. Powołanie i odwołanie wojewody następuje w drodze aktu administracyjnego. Jest to główna, prawna forma działania administracji publicznej, będąca opartym na przepisach prawa administracyjnego władczym rozstrzygnięciem (oświadczeniem woli) organu administracji publicznej, wydanym w konkretnej sprawie i dotyczącym indywidualnie określonego adresata ${ }^{25}$. Ten specyficzny akt administracyjny nie ma ani formy

${ }^{21}$ M. Chmaj, Wojewoda, urzqd wojewódzki, [w:] M. Chmaj (red.), Administracja Rzq̨dowa w Polsce, Warszawa 2012, s. 129-130.

${ }^{22}$ J. Ciapała, Administracja rzq̨dowa w terenie, [w:] A. Bałaban (red.), Rada Ministrów, organizacja i funkcjonowanie, Zakamycze 2002, s. 420.

${ }^{23}$ Tekst jedn. Dz. U. z 2019 r., poz. 1464.

${ }^{24}$ Art. 6 ust. 1 ustawy o wojewodzie i administracji rządowej w województwie.

${ }^{25}$ Obszernie na ten temat E. Komorowski, Prawne formy dziatania administracji, [w:] M. Chmaj (red.) Prawo administracyjne. Część ogólna, Warszawa 2007, s. 245-254 - podaję za M. Chmaj, Wojewoda, urząd wojewódzki, [w:] M. Chmaj (red.), op.cit., s. 131. 
decyzji administracyjnej, ani postanowienia, a w związku z tym nie przysługuje na niego odwołanie oraz skarga do sądu administracyjnego ${ }^{26}$.

Zgodnie z art. 8 ust. 1 ustawy o wojewodzie i administracji rządowej w województwie „Prezes Rady Ministrów kieruje działalnością wojewody, w szczególności wydając w tym zakresie wytyczne i polecenia, żądając przekazania sprawozdań z działalności wojewody oraz dokonując okresowej oceny jego pracy". Ponadto Prezes Rady Ministrów sprawuje nadzór nad działalnością wojewody na podstawie kryterium zgodności jego działania z polityką Rady Ministrów. Wiele uprawnień nadzorczych w stosunku do wojewody posiada również minister właściwy do spraw administracji publicznej, który sprawuje nadzór nad działalnością wojewody na podstawie kryterium zgodności jego działania z powszechnie obowiązującym prawem, a także pod względem rzetelności i gospodarności. Oczywiście te kompetencje ministra nie naruszają uprawnień właściwych ministrów w stosunku do wojewody, określonych w ustawie z dnia 14 czerwca 1960 r. - Kodeks postępowania administracyjnego ${ }^{27}$.

Wracając jednak do kwestii najistotniejszych ${ }^{28}$, jakie wynikają m.in. z tytułu artykułu to należy wyraźnie stwierdzić, iż w systemie nadzoru nad jednostkami samorządu terytorialnego wojewoda zajmuje szczególną pozycję ${ }^{29}$. Źródłem jego

${ }^{26}$ M. Chmaj, Wojewoda, urząd wojewódzki, [w:] M. Chmaj (red.), op.cit., s. 131.

27 Art. 8 ust. 4 ustawy o wojewodzie i administracji rządowej w województwie.

${ }^{28}$ Przedmiotem analiz w niniejszym artykule, odnoszących się praw, obowiązków jak i ustroju wojewody, są tylko wybrane zagadnienia.

${ }_{29}$ Zgodnie z art. 3 ustawy o wojewodzie i administracji rządowej w województwie (tekst jedn. Dz. U. z 2019 r., poz. 1464 wojewoda oprócz sprawowania nadzoru nad działalnością jednostek samorządu terytorialnego i ich związków jest również: przedstawicielem Rady Ministrów w województwie; zwierzchnikiem rządowej administracji zespolonej w województwie; organem rządowej administracji zespolonej w województwie; organem administracji rządowej w województwie, do którego właściwości należą wszystkie sprawy z zakresu administracji rządowej w województwie niezastrzeżone w odrębnych ustawach do właściwości innych organów tej administracji; reprezentantem Skarbu Państwa, w zakresie i na zasadach określonych w odrębnych ustawach; organem wyższego stopnia w rozumieniu ustawy z dnia 14 czerwca 1960 r. - Kodeks postępowania administracyjnego (Dz.U. z 2018 r. poz. 2096 oraz z 2019 r. poz. 60, 730 i 1133); obowiązany zapewnić gospodarowanie nieruchomościami Skarbu Państwa w województwie w sposób zgodny z zasadami prawidłowej gospodarki. Ponadto wojewoda kontroluje pod względem legalności, gospodarności i rzetelności wykonywanie przez organy samorządu terytorialnego zadań z zakresu administracji rządowej, realizowanych przez nie na podstawie ustawy lub porozumienia z organami administracji rządowej. Wojewoda również nadzoruje wykorzystanie zasobu nieruchomości Skarbu Państwa w województwie w szczególności poprzez: zatwierdzanie sporządzanych przez starostów, wykonujących zadania z zakresu administracji rządowej, planów realizacji polityki gospodarowania nieruchomościami Skarbu Państwa oraz ich zmian; określanie stopnia szczegółowości planu realizacji polityki gospodarowania nieruchomościami Skarbu Państwa; inicjowanie zmiany obowiązującego planu realizacji polityki gospodarowania nieruchomościami Skarbu 
kompetencji nadzorczych są nie tylko samorządowe ustawy ustrojowe, ale i wiele ustaw szczególnych. Ingerencja nadzorcza wojewody przejawia się możliwością podejmowania przez niego wielu środków nadzorczych. Są to nie tylko działania represyjne, ale i prewencyjne, kontrolne, poprzedzające właściwe akty nadzorcze, związane z nadzorem bieżącym czy też z sytuacjami nadzwyczajnymi ${ }^{30}$. Wojewoda korzysta ze swoich uprawnień nadzorczych najczęściej w związku z działalnością uchwałodawczą organów stanowiących i wykonawczych jednostek samorządu terytorialnego. Postępowanie nadzorcze (w trakcie którego organ nadzoru bada, czy uchwała organu jednostki samorządu terytorialnego jest czy też nie jest zgodna z prawem) kończy się (choć bardzo rzadko) wydaniem przez wojewodę rozstrzygnięcia nadzorczego. Zgodnie z definicją J. Zimmermanna, rozstrzygnięciem nadzorczym jest ,akt organu nadzorczego kończący postępowanie nadzorcze i konkretyzujący środek nadzoru, który organ chce zastosować" ${ }^{31}$.

Istotnym elementem kompetencji wojewody jest wydawanie zarządzeń zastępczych w przypadkach zaniechania organów samorządowych odnośnie do przekroczenia przez osoby pełniące funkcje publiczne zasad dotyczących ograniczeń prowadzenia działalności gospodarczej (art. 98a ustawy o samorządzie gminnym, art. 85a ustawy o samorządzie powiatowym, art. 86a ustawy o samorządzie województwa). Wojewodzie przysługują ponadto kompetencje nadzorcze związane z zastosowaniem określonych środków przez Prezesa RM (art. 96 ust. 2 , art. 97 ust. 3 ustawy o samorządzie gminnym, art. 83 ust. 2, art. 84 ust. 3 ustawy o samorządzie powiatowym, art. 84 ust. 2 , art. 85 ust. 3 ustawy o samorządzie województwa) ${ }^{32}$.

Państwa; występowanie do starosty, wykonującego zadanie z zakresu administracji rządowej, o sporządzenie w wyznaczonym terminie, nie krótszym niż dwa tygodnie, wykazu nieruchomości wchodzących w skład zasobu nieruchomości Skarbu Państwa w województwie, będących przedmiotem rozporządzenia; występowanie do starosty, wykonującego zadanie z zakresu administracji rządowej, o sporządzenie w wyznaczonym terminie, nie krótszym niż dwa tygodnie, wykazu postępowań sądowych, sądowoadministracyjnych lub administracyjnych, dotyczących nieruchomości wchodzących w skład zasobu nieruchomości Skarbu Państwa w województwie. Natomiast zadania i kompetencje wojewody w stanach nadzwyczajnych określają odrębne ustawy.

${ }_{30}$ Z. Kmieciak, M. Stahl, Akty nadzoru nad działalnością samorządu terytorialnego, ,Samorząd Terytorialny" 2001, nr 1-2, s. 97.

${ }_{31}$ J. Zimmermann, Elementy procesowe nadzoru i kontroli NSA nad samorzadem terytorialnym, „Państwo i Prawo” 1991, z. 10, s. 43-53.

${ }^{32}$ Szerzej do środków nadzoru będzie odnosił się pkt 5 artykułu. 


\section{PRZEDMIOT I KRYTERIUM NADZORU}

Odnośnie do przedmiotu nadzoru samorządowe ustawy ustrojowe używają wielu sformułowań. Swoje krótkie rozważania w niniejszym punkcie oprę głównie na wybranych przepisach samorządowych ustaw ustrojowych. Przykładowo art. 76 ust. 1 ustawy o samorząazie powiatowym odnosi się do nadzoru nad działalnością powiatu, z kolei art. 77 stanowi o nadzorze nad wykonywaniem zadań powiatu ${ }^{33}$. Natomiast Konstytucja RP w cytowanym już art. 171 ust. 1 idzie $\mathrm{w}$ tej materii jeszcze dalej, albowiem nie różnicuje działalności samorządu terytorialnego, która będzie podlegać nadzorowi. Tak więc ani samorządowe ustawy ustrojowe, ani Konstytucja nie rozstrzyga w jasny sposób, czy nadzór ma być sprawowany nad wykonywaniem zadań własnych, czy też obejmuje wykonywanie zadań zleconych ${ }^{34}$. Powyższą kwestię sporną rozstrzygnął Trybunał Konstytucyjny w uchwale z dnia 27 września 1994 r., który pojęcie działalności komunalnej zinterpretował w bardzo szerokim znaczeniu. Stanął na stanowisku, że „działalnością komunalną w rozumieniu art. 85 i 87 ustawy z dnia 8 marca 1990 r. o samorządzie terytorialnym [...] jest wszelka działalność gmin oraz innych wymienionych w tej ustawie jednostek samorządu terytorialnego" ${ }^{35}$. Trybunał Konstytucyjny potwierdził tym samym orzecznictwo Naczelnego Sądu Administracyjnego, który także przyjął, że „,na podstawie art. 85-100 ustawy o samorządzie terytorialnym zakresem nadzoru nad działalnością komunalną są objęte wszystkie uchwały organów gminy, a nie tylko uchwały będące aktami normatywnymi ogólnie obowiązującymi, tj. przepisami gminnymi" ${ }^{36}$. Cytowane orzeczenie Naczelnego Sądu Administracyjnego, jak i orzeczenie Trybunału Konstytucyjnego zachowuje pełną aktualność również w odniesieniu do pozostałych jednostek samorządu terytorialnego.

Oczywiście spod ingerencji nadzorczej należy bezwzględnie wyłączyć decyzje administracyjne, jakie wydawane są głównie przez organ wykonawczy

33 Z. Janku, Nadzór nad samorzqdem powiatowym, [w:] J. Boć (red.), Powiat, Kolonia Limited 2001, s. 183.

34 Zob. Z. Niewiadomski, Nadzór nad samorzq̨em terytorialnym, [w:] Z. Niewiadomski (red.), Samorząd terytorialny ustrój i gospodarka, Bydgoszcz-Warszawa 2001, s. 203-204; Z. Niewiadomski, Samorząd terytorialny w Konstytucji RP, ,Samorząd Terytorialny” 2000, nr 3, s. 26; Z. Leoński, Samorzqd terytorialny w III RP, Warszawa 2020, s. 177-178; Z. Leoński, Nadzór nad samorzqdem terytorialnym, [w:] A. Piekara, Z. Niewiadomski (red.), Samorząd terytorialny zagadnienia prawne $i$ administracyjne, Warszawa 1998, s. 231-232.

${ }_{35}$ W 10/93, OTK 1994, nr 2, poz. 46.

${ }^{36}$ Wyrok Naczelnego Sądu Administracyjnego - Ośrodek Zamiejscowy we Wrocławiu z dnia 19 marca 1992 r., SA/Wr 104/92, „Wspólnota” 1993, nr 3, s. 14. 
samorządu terytorialnego $\mathrm{w}$ indywidualnych sprawach $\mathrm{z}$ zakresu administracji publicznej. W tym zakresie kontrolę instancyjną, nadzór instancyjny i kontrolę sprawowaną przez sąd administracyjny regulują odrębne przepisy, a w szczególności przepisy Kodeksu postępowania administracyjnego ${ }^{37}$ i Ordynacji podatkowej ${ }^{38}$.

Jeżeli zaś chodzi o kryterium nadzoru nad działalnością jednostek samorządu terytorialnego, to zarówno Konstytucja RP, jak i samorządowe ustawy ustrojowe przyjmują jako jedyne kryterium legalności (zgodności z prawem) ${ }^{39}$. Dlatego też organy nadzoru mogą wkraczać w działalność komunalną jedynie w przypadku naruszenia prawa ${ }^{40}$. Wówczas to celem nadzoru staje się powrót do stanu zgodnego z prawem. Nie jest jednak możliwe, by organ nadzoru ingerował w merytoryczną działalność gminy, powiatu czy też województwa samorządowego.

Ustawodawca konstytucyjny intencjonalnie zrezygnował z celowości jako kryterium nadzoru nad samorządem terytorialnym, wychodząc z założenia, iż samorząd powinien mieć zapewnioną jak najszerszą samodzielnośćc1 . Należy także pamiętać, iż prowadząc nadzór nad działalnością samorządu powiatowego (oraz gminnego i wojewódzkiego), nie można poprzestać na zbadaniu zgodności uchwał organów powiatu z ustawami. Organ nadzoru musi wziąć pod uwagę także zgodność tych uchwał z innymi określonymi w art. 87 Konstytucji źródłami prawa, tzn. z Konstytucją, ratyfikowanymi umowami międzynarodowymi, rozporządzeniami wydanymi na podstawie szczegółowego upoważnienia zawartego w ustawie i w celu jej wykonania oraz z aktami prawa miejscowego.

Jeżeli zaś chodzi o kryteria zgodności uchwał z prawem, jakimi organ nadzoru powinien się kierować, to przede wszystkim musi wziąć pod uwagę aspekt

37 Ustawa z dnia 14 czerwca 1960 r. Kodeks postępowania administracyjnego (tekst jedn.: Dz. U. z 2020 r., poz. 256, z późn. zm.).

38 Ustawa z dnia 29 sierpnia 1997 r. Ordynacja podatkowa (tekst jedn.: Dz. U. z 2017 r., poz. 201, z późn. zm.).

${ }^{39}$ Zob. art. 171 ust. 1 Konstytucji i art. 76 ustawy o samorządzie powiatowym. Zob. także E. Knosala, Instytucja nadzoru nad jednostkami samorzadu terytorialnego $w$ świetle ostatnich zmian ustawodawczych, [w:] S. Dolata (red.), Problemy prawne w działalności samorzadu terytorialnego, Opole 2002, s. 47-49.

${ }^{40}$ Co istotne, do czasu wejścia w życie ustawy z dnia 11 kwietnia 2001 r. o zmianie ustaw: o samorządzie gminnym, o samorządzie powiatowym, o samorządzie województwa, o administracji rządowej w województwie oraz o zmianie niektórych innych ustaw (Dz. U. z 2001 r., nr 45, poz. 497) obowiązywał art. 85 ust. 2 ustawy o samorządzie gminnym, który to wprowadzał dwa kryteria sprawowania nadzoru: legalność i celowość (celowość, rzetelność, gospodarność). Przepis ten był ewidentnie sprzeczny z art. 171 ust. 1 Konstytucji RP.

41 Z. Niewiadomski, Samorzą terytorialny w Konstytucji..., s. 26. 
formalny i merytoryczny. Pierwszy obejmuje spełnienie formalnych warunków podjęcia uchwały przez organ jednostki samorządu terytorialnego, drugi natomiast - zgodność postanowień uchwały z treścią obowiązującego prawa ${ }^{42}$.

Nieco inaczej kompetencje w ramach nadzoru (czym w ramach niniejszego artykułu się nie zajmuje) uregulowane są w ustawie o regionalnych izbach obrachunkowych ${ }^{43}$.

\section{5. ŚRODKI NADZORCZE ${ }^{44}$}

Samorządowe ustawy ustrojowe przewidują liczne środki nadzorcze, przez które należy rozumieć formy ingerencji w działalność gminy, powiatu czy też województwa samorządowego przez organy, które zarówno przez ustrojodawcę, jak i ustawodawcę zostały powołane do sprawowania nadzoru. Intensywność i rodzaj zastosowanych środków nadzoru ściśle określają ustawy. Dodatkowo, aby ingerencja organów nadzoru w działalność samorządu nie powodowała zbytniego ograniczania jego samodzielności, zagwarantowane zostało prawo do kwestionowania aktów nadzoru przed sądami administracyjnymi.

W doktrynie środki nadzorcze klasyfikowane są w różny sposób ${ }^{45}$. W niniejszej pracy przyjmuję klasyczny podział środków nadzoru na środki kontroli i środki korygujące. Natomiast środki nadzoru nad sferą wykonywania zadań zleconych zostaną (ze względu na pewną specyfikę) omówione oddzielnie.

${ }^{42}$ Zob. także A. Szewc, Legalność uchwał organów gminy, „Samorząd Terytorialny” 1998, nr 6, s. 10-16 oraz Wyrok Naczelnego Sądu Administracyjnego - Ośrodek Zamiejscowy we Wrocławiu z dnia 11 maja 1993 r., SA/Wr 432/93, OSP 1995, nr 2, poz. 28, w którym to Naczelny Sąd Administracyjny stwierdził m.in.: „Kontrola legalności uchwał organów gminy nie może ograniczać się do porównania przedmiotu uchwały z przepisem kompetencyjnym stanowiącym jej podstawę; kontrola ta musi rozciągać się na wszystkie etapy procesu stosowania prawa przez radę gminy, jeśli kończy się on podjęciem uchwały. Nie jest więc od niej wolna również prawidłowość ustaleń faktycznych, jeżeli prawo materialne uzależnia określone rozstrzygnięcie lub unormowanie ogólne od wystąpienia określonych przesłanek faktycznych".

${ }^{43}$ Ustawa z dnia 7 października 1992 r. o regionalnych izbach obrachunkowych, tekst jedn. Dz. U. z 2019 r., poz. 2137.

${ }^{44}$ Szerzej na temat środków nadzoru - zob.: S. Bułajewski, op.cit., s. 227-234.

${ }^{45}$ Przykładowo B. Dolnicki dzieli środki nadzorcze, dotyczące zadań własnych samorządu, na środki informacyjno-doradcze, korygujące i personalne (zob. B. Dolnicki, Samorząd terytorialny zagadnienia ustrojowe, Zakamycze 1999, s. 178; B. Dolnicki, Klasyfikacja środków nadzorczych nad samorzadem terytorialnym w ustawodawstwie polskim, „Samorząd Terytorialny” 1997, nr 6, s. 45). Z kolei Z. Niewiadomski wyróżnia: środki informacyjne, ostrzegawcze i prewencyjne oraz represyjne (zob. Z. Niewiadomski, Samorzqd terytorialny - ustrój..., s. 207). 
Środki kontroli przewidziane są w niewielu artykułach. Przykładowo w art. 88 ustawy o samorządzie gminnym ,organy nadzoru mają prawo żądania informacji i danych, dotyczących organizacji i funkcjonowania gminy, niezbędnych do wykonywania przysługujących im uprawnień nadzorczych.”. W artykule tym uregulowany został tzw. obowiązek informacyjny, który bezpośrednio wynika z zasady jawności działania organów gminy. Co prawda ustawa o samorządzie gminnym nie zawiera żadnego przepisu, który zezwalałby organom nadzorczym na uczestnictwo w posiedzeniach organów samorządu powiatowego, jednakże moim zdaniem to prawo im przysługuje na mocy art. 61 ust 1 Konstytucji, który daje takie uprawnienie każdemu obywatelowi polskiemu ${ }^{46}$.

Kolejny obowiązek o charakterze informacyjnym wynika z art. 90 ustawy o samorządzie gminnym, który zobowiązuje wójta do przedłożenia wojewodzie uchwał rady w ciągu 7 dni od dnia ich podjęcia, a w przypadku aktów ustanawiających przepisy porządkowe - w ciągu 2 dni od dnia ich ustanowienia. $\mathrm{Na}$ powyższych zasadach wójt przedkłada regionalnej izbie obrachunkowej uchwałę budżetową, uchwałę w sprawie absolutorium dla wójta oraz inne uchwały rady gminy i zarządzenia wójta objęte zakresem nadzoru regionalnej izby obrachunkowej $^{47}$.

Ustawa o samorządzie gminnym (tak jak i inne samorządowe ustawy ustrojowe) nie przewiduje jednak żadnej sankcji w przypadku przekroczenia przez wójta 7-dniowego terminu na dostarczenie organowi nadzoru ww. uchwał. Naczelny Sąd Administracyjny ${ }^{48}$ i Sąd Najwyższy rozstrzygnęły analogicznie tę kwestię w swoich orzeczeniach, uznając termin 7-dniowy za instrukcyjny. W powyższych orzeczeniach podniesiono, iż przekroczenie przez organy wykonawcze samorządu terminu przedłożenia wojewodzie uchwał rady nie pociąga za sobą ujemnych skutków prawnych co do samej uchwały, jak i nie stanowi przeszkody do podjęcia przez wojewodę działań nadzorczych prowadzących do stwierdzenia nieważności nieprzedłożonej terminowo uchwały, nawet gdy od daty jej podjęcia upłynął już rok.

Jak więc łatwo możemy zauważyć, środki kontroli nie stanowią bezpośredniej ingerencji w działania organów jednostek samorządu terytorialnego. Podstawowym celem informacyjnych środków nadzoru jest uzyskanie informacji o działalności samorządu, a następnie (jeśli będzie to konieczne) mogą być za-

${ }^{46}$ Zob. podobnie, B. Dolnicki, Komentarz do art. 77a ustawy o samorzadzie powiatowym, [w:] B. Dolnicki (red.), Ustawa o samorzadzie powiatowym komentarz, Zakamycze 2005, s. 468-469.

${ }^{47}$ Art. 90 ustawy o samorządzie gminnym.

${ }^{48}$ Zob. wyrok Naczelnego Sądu Administracyjnego - Ośrodek Zamiejscowy w Gdańsku z dnia 22 listopada 1990 r., SA/Gd 965/90, ONSA 1990, nr 4, poz. 11 oraz wyrok Sądu Najwyższego z dnia 9 września 1993 r., III ARN 42/93, OSNC 1994, nr 5, poz. 111. 
stosowane środki nadzoru o charakterze korygującym, które powinny przywrócić stan zgodny z prawem.

Środki korygujące, odmiennie niż środki kontroli, mogą ingerować w sposób władczy w sferę aktywności samorządu. Ich lista w samorządowych ustawach ustrojowych, jak słusznie zauważył Z. Leoński, została ustalona według stopnia ich intensywności ${ }^{49}$.

Pierwszym środkiem nadzorczym jest zatwierdzanie, uzgadnianie lub zaopiniowanie przez inny organ (niekoniecznie przez organ nadzorczy) rozstrzygnięć organów samorządowych ${ }^{50}$. Uzgodnienie w przeciwieństwie do opinii ma charakter wiążący dla rady, natomiast zatwierdzenie dotyczy zazwyczaj już wydanego rozstrzygnięcia. Obowiązek uzyskania zatwierdzenia, opinii lub uzgodnienia wynika najczęściej z przepisów prawa materialnego. Przewidziany zaś w powyższym artykule 14- oraz 30-dniowy termin nie ma charakteru instrukcyjnego ${ }^{51}$. Jeżeli stanowisko $\mathrm{w}$ formie zatwierdzenia, uzgodnienia lub opinii nie zostanie w ciągu 14 dni przedstawione organowi nadzoru przez organ zewnętrzny, to należy uznać, iż rozstrzygnięcie $\mathrm{w}$ danej sprawie zostało przyjęte $\mathrm{w}$ brzmieniu proponowanym przez organ jednostki samorządu terytorialnego. Jeżeli zaś organem mającym zająć stanowisko jest organ stanowiący jednostki samorządu terytorialnego, to termin wynosi nie 14, lecz aż 30 dni. Dzięki przepisom art. 89 ust. 2 ustawy o samorządzie gminnym zarówno organy gminy, jak i inne organy administracji chronione są przed wzajemną bezczynnością ${ }^{52}$.

Drugim i najczęściej stosowanym środkiem nadzoru nad działalnością jednostek samorządu terytorialnego jest orzekanie o nieważności uchwał lub zarządzeń organów jednostek samorządu terytorialnego. Jest to środek represyjny, realizowany w stosunku do sprzecznych z prawem wszystkich uchwał zarówno rady gminy, powiatu, sejmiku województwa zarządzeń wójta, czy też uchwał zarządu powiatu czy tez zarządu województwa. Tym samym w kręgu zainteresowania organów nadzoru mieścić się będą nie tylko akty prawa miejscowego. W ramach tego środka możemy wyróżnićs3:

a) stwierdzenie nieważności uchwały rady lub zarządzenia organu wykonawczego,

49 Z. Leoński, Samorząd terytorialny..., s. 185.

${ }^{50}$ Art. 89 ustawy o samorządzie gminnym.

${ }^{51}$ Zob. P. Chmielnicki, Komentarz do art. 77b ustawy o samorzadzie powiatowym, [w:] P. Chmielnicki (red.), Komentarz do ustawy o samorzqdzie powiatowym, Warszawa 2005, s. 476-477.

${ }^{52}$ Ibidem, s. 477-488. Zob. także E. C. Malisz, Samorzqdowe prawo miejscowe. Praktyczny poradnik, Zielona Góra 2001, s. 99-103.

${ }^{53}$ Podobny podział przedstawili: A. Szewc, T. Szewc, Uchwałodawcza działalność organów samorzqdu terytorialnego, Warszawa 1999, s. 146. 
b) wstrzymanie wykonania uchwały,

c) wskazanie, że uchwałę wydano z naruszeniem prawa,

d) zaskarżenie uchwały do sądu administracyjnego,

e) orzeczenie o niezgodności uchwały z prawem,

f) rozstrzygnięcie sprawy za organ jednostki samorządu terytorialnego.

Ad a. Zasada, że uchwała organu jednostki samorządu terytorialnego sprzeczna z prawem jest nieważna ma pełne zastosowanie zarówno do uchwał podejmowanych przez organ stanowiący gminy, powiatu, województwa jak i do organów wykonawczych ${ }^{54}$. O nieważności uchwały orzeka właściwy organ nadzoru w terminie 30 dni od doręczenia uchwały. Co istotne, postępowanie organu nadzoru w sprawie stwierdzenia nieważności uchwały podjętej przez organ powiatu jest wszczynane i prowadzone jedynie $\mathrm{z}$ urzędu ${ }^{55}$.

Organ nadzorczy, wydając rozstrzygnięcie, poddaje ocenie nie tylko warunki formalne powstania uchwały, ale i jej materialną treść. Może także, wszczynając postępowanie w przedmiocie stwierdzenia nieważności uchwały, wstrzymać jej wykonanie. Końcowym efektem pracy organu nadzoru (w przypadku stwierdzenia sprzeczności uchwały z prawem) jest wydanie rozstrzygnięcia nadzorczego, w którym stwierdza się nieważność uchwały w całości lub w części albo informacja o odstąpieniu od takiego zamiaru ${ }^{56}$.

Co istotne, jak trafnie wskazał Naczelny Sąd Administracyjny w wyroku z dnia 12 października 1990 r. ,,[...] orzeczenie o stwierdzeniu nieważności uchwały organu gminy przez organ nadzoru (wojewodę) wydane być może tylko wtedy, gdy uchwała taka pozostaje w wyraźnej sprzeczności z określonym przepisem prawnym i gdy wynika to wprost z treści takiego przepisu. Dochodzenie do wniosku, iż uchwała organu gminy jest sprzeczna z prawem w drodze zawiłej nieraz wykładni określonego przepisu prawnego, a szczególnie, gdy zachodzić może w tym przedmiocie niejednolitość poglądów prawnych, powodować może negatywne następstwa społeczne niezamierzone przez ustawodawcę, w postaci ograniczania samodzielności organów samorządu terytorialnego przez organy nadzoru. Dlatego też orzeczenia organów nadzoru w tym przedmiocie win-

${ }^{54}$ Zob. wyrok Trybunału Konstytucyjnego z dnia 9 grudnia 2003 r., P 9/02, OTK 2003, nr 9A, poz. 100.

55 Zob. wyrok Naczelnego Sądu Administracyjnego - Ośrodek Zamiejscowy we Wrocławiu z dnia 8 kwietnia 1992 r., SAB/Wr 15/92, ONSA 1993, nr 2, poz. 39 oraz postanowienie Naczelnego Sądu Administracyjnego - Ośrodek Zamiejscowy we Wrocławiu z dnia 8 kwietnia 1992 r., SAB/Wr 16/92, ONSA 1993, nr 2, poz. 39.

${ }_{56}$ Zob. wyrok Naczelnego Sądu Administracyjnego - Ośrodek Zamiejscowy we Wrocławiu z dnia 15 stycznia 1992 r., SA/Wr 22/92, ONSA 1993, nr 1, poz. 15. 
ny mieć zawsze nie budzącą wątpliwości podstawę prawną" ${ }^{57}$. Z powyższego orzeczenia wynika więc, iż rozstrzygnięcia nadzorcze skutkujące nieważnością uchwały powinny być wydawane jedynie w przypadku istotnego naruszenia prawa przez akt podjęty przez organ powiatu. Zgodnie z wyrokiem Naczelnego Sądu Administracyjnego z dnia 11 lutego 1998 r., istotnym naruszeniem prawa jest , ,...] naruszenie: przepisów wyznaczających kompetencję do podejmowania uchwał, podstawy prawnej podejmowania uchwał, przepisów prawa ustrojowego, przepisów prawa materialnego - przez wadliwą ich wykładnię - oraz przepisów regulujących procedurę podejmowania uchwał" ${ }^{58}$.

Przepisy samorządowych ustaw ustrojowych stanowią także, że rozstrzygnięcie nadzorcze powinno zawierać uzasadnienie faktyczne i prawne oraz obligatoryjnie pouczenie o dopuszczalności wniesienia skargi do sądu administracyjnego.

Jeżeli chodzi zaś o prawomocność rozstrzygnięcia nadzorczego, to następuje to z upływem terminu do wniesienia skargi do sądu administracyjnego lub z datą oddalenia lub odrzucenia skargi przez sąd. Podstawowym natomiast skutkiem stwierdzenia nieważności uchwały jest wyeliminowanie jej z obrotu prawnego ze skutkiem ex tunc, tj. od momentu jej podjęcia ${ }^{59}$.

Ad b. Organ nadzoru, wszczynając postępowanie w sprawie stwierdzenia nieważności uchwały, jak również w jego toku, może wstrzymać wykonanie uchwały ${ }^{60}$. W tym przypadku czynność ta ma zatem charakter fakultatywny. Na organ nadzoru nałożony jest także obowiązek wydania w powyższej kwestii stosownego postanowienia, które tak jak rozstrzygnięcie nadzorcze powinno zawierać uzasadnienie faktyczne i prawne oraz pouczenie o możliwości jego zaskarżenia do sądu administracyjnego. Co istotne, organ nadzoru traci uprawnienie wstrzymania wykonania uchwały, jeżeli upłynął już 30-dniowy termin przewidziany na stwierdzenie jej nieważności. W przypadku zaś zaskarżenia uchwały do sądu, postanowienie o wstrzymaniu jej wykonania może podjąć jedynie sąd administracyjny.

${ }^{57}$ Zob. wyrok Naczelnego Sądu Administracyjnego - Ośrodek Zamiejscowy w Lublinie, z dnia 12 października 1990 r., SA/Lu 663/90, ONSA 1990, nr 4, poz. 6.

${ }^{58}$ II SA/Wr 1459/97; OSS 1998, nr 3, poz. 79. Zob. także J. Czerw, Nadzór nad działalnościq prawodawczq, „Wspólnota” 2003, nr 16, s. 46-48.

${ }^{59}$ Potwierdził to w jednym z orzeczeń także Naczelny Sąd Administracyjny (zob. przypis 45), w którym wskazał, iż ,orzeczenie wojewody o stwierdzenie nieważności uchwały organu gminy ma charakter deklaratoryjny i działa wstecz (ex tunc), bo nieważna jest z mocy prawa od chwili jej podjęcia".

${ }^{60}$ Art. 91 ust. 2 ustawy o samorządzie gminnym. 
Ad c. $\mathrm{W}$ przypadku nieistotnego naruszenia prawa ${ }^{61}$ przez uchwałę lub inny akt normatywny podjęty przez jednostki samorządu terytorialnego organ nadzoru nie stwierdza nieważności uchwały, a jedynie ogranicza się do wskazania, iż uchwałę wydano z naruszeniem prawa.

Ad d. Zgodnie z cytowanym już art. 91 ust. 1 ustawy o samorządzie gminnym organ nadzoru ma 30 dni na stwierdzenie nieważności uchwały. Jeżeli w powyższym terminie organ nadzoru nie wyda rozstrzygnięcia, to pozostaje jedynie możliwość zaskarżenia uchwały sprzecznej z prawem do sądu administracyjnego. Jednakże sąd administracyjny także traci uprawnienie do stwierdzenia nieważności uchwały podjętej przez organ radę gminy w sytuacji, gdy upłynął już rok od jej podjęcia. Wyjątkiem są akty prawa miejscowego lub zarządzenia, w stosunku do których sąd administracyjny może także po upływie roku stwierdzić nieważność takiego aktu.

Ad e. Jeżeli w ciągu 30 dni od daty doręczenia uchwały organowi nadzoru nie stwierdzi on jej nieważności, to kompetencja ta przechodzi na sąd administracyjny na skutek skargi wniesionej przez ten organ. Natomiast jeśli od daty podjęcia uchwały upłynął już rok, to nie można stwierdzić jej nieważności, chyba że naruszony został termin do jej przedłożenia organowi nadzoru. Także jeżeli istnieją przesłanki do stwierdzenia nieważności uchwały organu jednostki samorządu terytorialnego, sąd administracyjny orzeka o niezgodności uchwały z prawem.

Ad f. Kolejnym środkiem nadzoru, przewidzianym w samorządowych ustawach ustrojowych jest rozstrzygnięcie sprawy za organ jednostki samorządowej, tj. wydanie zarządzenia zastępczego. Zgodnie z art. 98a ustawy o samorządzie gminnym, jeżeli właściwy organ gminy zaniecha podjęcia działań, do których zobowiązują go odpowiednie przepisy wyrażone w ustawach szczegółowych ${ }^{62}$, to $w$ takiej sytuacji wojewoda wzywa organ gminy do podjęcia odpowiedniego aktu w terminie 30 dni. W razie natomiast bezskutecznego upływu powyższego terminu, wojewoda (po powiadomieniu ministra właściwego do spraw administracji publicznej) wydaje zarządzenie zastępcze ${ }^{63}$.

${ }^{61}$ Pojęcie nieistotnego naruszenia prawa ma charakter nieostry i dlatego moim zdaniem organ nadzoru może każdorazowo dokonywać jego wykładni, co niestety powoduje, iż samodzielność organów samorządu terytorialnego (ze względu na dużą swobodę interpretacyjną pojęć „istotne” i „nieistotne”) nie jest dostatecznie zabezpieczona. Zob. także Z. Kmieciak, W sprawie nieistotnego naruszenia prawa przez uchwate budżetowa, „Samorząd Terytorialny” 1994, nr 3, s. $28-32$.

62 Art. 5 ust. 2, 3 i 5 ustawy z dnia 21 sierpnia 1997 r. o ograniczeniu prowadzenia działalności gospodarczej przez osoby pełniące funkcje publiczne (Dz. U. z 1997 r., nr 113, poz. 984 z późn. zm.), art. 190 ust. 2 i 6 ustawy z dnia 16 lipca 1998 r. Ordynacja wyborcza do rad gmin, rad powiatów i sejmików województw (tekst jedn. z 2003, nr 159, poz. 1547 z późn. zm.)

${ }_{63}$ Art. 85 a ust. 2 ustawy o samorządzie powiatowym. 


\section{PODSUMOWANIE}

Celem niniejszego artykułu była krótka charakterystyka instytucji wojewody. Z jednej strony ten konstytucyjny organ działa m.in. w sferze politycznej, jako przedstawiciel Rady Ministrów, natomiast z drugiej - jako organ nadzoru (w naszym wypadku nadzoru nad działalnością jednostek samorządu terytorialnego) realizuje swoje kompetencje, kierując się kryterium legalności. Moją intencją nie było przedstawienie tego podmiotu jako takiego. Jednakże analizując zaprezentowane rozważania, możemy wypracować kilka wniosków.

Po pierwsze - wojewoda to od 1990 r. konstytucyjny organ państwa, którego ustrojodawca (obok Prezesa RM i Regionalnej Izby Obrachunkowej) zaliczył do organów nadzoru nad samorządem terytorialnym.

Po drugie - umieszczenie wojewody w ustawie zasadniczej pociąga za sobą szereg skutków ustrojowych. Likwidacja tego organu, lub choćby przeniesienie go do administracji zdecentralizowanej nie jest możliwa bez nowelizacji obecnie obowiązującej Konstytucji RP ${ }^{64}$.

Po trzecie - przyznanie samodzielności samorządowi terytorialnemu znajduje wyraz normatywny w konstrukcji normatywnej nadzoru. Ustawa zasadnicza reguluje dwa główne elementy konstrukcji nadzoru nad jednostkami samorządu terytorialnego: $\mathrm{z}$ jednej strony kryterium ingerencji nadzorczej - czyli legalność (art. 171 ust. 1 Konstytucji RP) a z drugiej strony wskazuje organy powołane do sprawowania nadzoru, przyznając w tym zakresie kompetencje m.in. wojewodzie (art. 171 ust. 2 Konstytucji RP) ${ }^{65}$.

Po czwarte - wojewoda, tak jak i inne wskazane w Konstytucji RP organy nadzoru, niezależnie od kompetencji nadzorczych posiada kompetencje kontrolne.

Po piąte - postepowanie nadzorcze jest postępowaniem jednoinstancyjnym. Zarówno jego wstrzymanie, jak i uchylenie podlega zaskarżeniu do Wojewódzkiego Sądu Administracyjnego.

Po szóste - wojewoda jako organ nadzoru nad działalnością jednostek samorządu terytorialnego nie jest związany nie tylko rozstrzygnięciami nadzorczymi wydanymi w analogicznych sprawach przez wojewodów z innych województw, ale i nie wiążą ich rozstrzygnięcia sądów administracyjnych, które zakresem swojego działania nie obejmują zakresu działalności konkretnego wojewody ${ }^{66}$.

${ }^{64}$ M. Chmaj, Wojewoda, urząd wojewódzki, [w:] M. Chmaj (red.), op.cit., s. 130.

${ }^{65}$ Ibidem, s. 140.

${ }^{66}$ Obszernie na ten temat: S. Bułajewski, Problematyka aktów prawa miejscowego $w$ rozstrzygnięciach nadzorczych wojewody i orzeczeniach sąów administracyjnych, [w:] B. Dolnicki (red.), Źródła prawa w samorzqdzie terytorialnym, Warszaw 2018, s. 118-127. 


\section{BIBLIOGRAFIA:}

Boć J., Kontrola administracji, [w:] J. Boć (red.), Administracja publiczna, Kolonia Limited 2003.

Bułajewski S., Rada powiatu, pozycja ustrojowa, stanowienie prawa i kontrola, Olsztyn 2009.

Bułajewski S., Problematyka aktów prawa miejscowego $w$ rozstrzygnięciach nadzorczych wojewody i orzeczeniach sąów administracyjnych, [w:] B. Dolnicki (red.), Źródła prawa w samorzq̨dzie terytorialnym, Warszawa 2018.

Chmaj M., Wojewoda, urząd wojewódzki, [w:] M. Chmaj (red.), Administracja rzqdowa w Polsce, Warszawa 2012.

Chmielnicki P., Nadzór nad działalnością samorząu terytorialnego. Rozważania de lege ferenda, „Przegląd Legislacyjny” 2004, nr 5.

Chmielnicki P., Komentarz do art. 77 b ustawy o samorzqdzie powiatowym, [w:] P. Chmielnicki (red.), Komentarz do ustawy o samorzadzie powiatowym, Warszawa 2005.

Ciapała J., Administracja rzq̨dowa w terenie, [w:] A. Bałaban (red.), Rada Ministrów, organizacja i funkcjonowanie, Zakamycze 2002.

Czerw J., Nadzór nad działalnościa prawodawczq, ,,Wspólnota” 2003, nr 16.

Dolnicki B., Klasyfikacja środków nadzorczych nad samorządem terytorialnym w ustawodawstwie polskim, „Samorząd Terytorialny” 1997, nr 6,

Dolnicki B., Nadzór nad samorzq̨dem terytorialnym, Katowice 1993.

Dolnicki B., Samorzad terytorialny zagadnienia ustrojowe, Zakamycze 1999.

Dolnicki B., (red.) Ustawa o samorzadzie powiatowym komentarz, Zakamycze 2005.

Filipowicz A., Pojęcie i funkcje nadzoru $w$ administracji, Wrocław - Warszawa - Kraków - Gdańsk 1985.

Homplewicz J., Ogólne zagadnienia prawne kontroli administracji, „Kontrola Państwowa" 1965, z. 4.

Jagielski J., Kontrola administracji publicznej, Warszawa 2006.

Janku Z., Nadzór nad samorzq̨dem powiatowym, [w:] J. Boć (red.), Powiat, Kolonia Limited 2001.

Jędrzejewski S., Teoretyczne problemy rozgraniczenia pojęć „,kontrola” $i$ „,nadzór”, [w:] S. Jędrzejewski, H. Nowicki, Kontrola administracji publicznej, Toruń 1995.

Miemiec W., Nadzór i kontrola nad samorządem terytorialnym, [w:] W. Miemiec, B. Cybulski (red.), Samorządowy poradnik budżetowy na 1997 r. Zagadnienia ustrojowe i prawno-finansowe, Warszawa 1997.

Kmieciak Z., Stahl M., Akty nadzoru nad działalnościq samorzq̨du terytorialnego, ,Samorząd Terytorialny" 2001, nr 1-2.

Kmieciak Z., W sprawie nieistotnego naruszenia prawa przez uchwałe budżetowa, ,Samorząd Terytorialny" 1994, nr 3. 
Knosala E., Instytucja nadzoru nad jednostkami samorządu terytorialnego $w$ świetle ostatnich zmian ustawodawczych, [w:] S. Dolata (red.), Problemy prawne $w$ dziatalności samorządu terytorialnego, Opole 2002.

Komorowski E., Prawne formy działania administracji, [w:] M. Chmaj (red.) Prawo administracyjne. Część ogólna, Warszawa 2007.

Leoński Z., Samorzą terytorialny w III RP, Warszawa 2002.

Leoński Z., Nadzór nad samorzqdem terytorialnym, [w:] A. Piekara, Z. Niewiadomski (red.), Samorzad terytorialny zagadnienia prawne i administracyjne, Warszawa 1998.

Malisz E. C., Samorzqdowe prawo miejscowe. Praktyczny poradnik, Zielona Góra 2001.

Niewiadomski Z., Nadzór nad samorzq̨dem terytorialnym, [w:] Z. Niewiadomski (red.), Samorząd terytorialny ustrój i gospodarka, Bydgoszcz-Warszawa 2001.

Niewiadomski Z., Samorząd terytorialny w Konstytucji RP, „Samorząd Terytorialny” 2000, nr 3.

Ochendowski E., Prawo administracyjne część ogólna, Torun 2005.

Safjan M., Bosek L. (red.), Konstytucja RP, tom III, Warszawa 2016, wyd. 1. /Skoczylas/ Piątek - wydawnictwo elektroniczne Legalis, dostęp - 1 lipca 2020 r.

Starościak J., Zarys nauki administracji, Warszawa 1971.

Starościak J., Prawo administracyjne, Warszawa 1975.

Szewc A., Legalność uchwał organów gminy, „Samorząd Terytorialny” 1998, nr 6.

Szewc A., Szewc T., Uchwałodawcza działalność organów samorzqdu terytorialnego, Warszawa 1999.

Szewczyk M., Nadzór w materialnym prawie administracyjnym, Poznań 1995

Wierzbowski M., Nadzór $w$ systemie rad narodowych $i$ terenowych organów administracji, [w:] J. Służewski (red.), Terenowe organy administracji $i$ rady narodowe po reformie, Warszawa 1977.

Zimmermann J., Elementy procesowe nadzoru i kontroli NSA nad samorzadem terytorialnym, „Państwo i Prawo” 1991. 